University of Nebraska - Lincoln

DigitalCommons@University of Nebraska - Lincoln

\title{
Thalassiosira praeoestrupii A New Diatom Species for Recognizing the Miocene/Pliocene Epoch Boundary in Coastal California
}

\author{
Michael P. Dumont \\ University of California, Berkeley \\ Jack G. Baldauf \\ Texas A\&M University, College Station, Texas \\ John A. Barron \\ USGS
}

Follow this and additional works at: https://digitalcommons.unl.edu/usgsstaffpub

Part of the Earth Sciences Commons

Dumont, Michael P.; Baldauf, Jack G.; and Barron, John A., "Thalassiosira praeoestrupii- A New Diatom Species for Recognizing the Miocene/Pliocene Epoch Boundary in Coastal California" (1986). USGS Staff -- Published Research. 267.

https://digitalcommons.unl.edu/usgsstaffpub/267

This Article is brought to you for free and open access by the US Geological Survey at DigitalCommons@University of Nebraska - Lincoln. It has been accepted for inclusion in USGS Staff -- Published Research by an authorized administrator of DigitalCommons@University of Nebraska - Lincoln. 


\title{
Thalassiosira praeoestrupii-a new diatom species for recognizing the Miocene/Pliocene Epoch boundary in coastal California
}

\author{
Michael P. Dumont, ${ }^{1}$ Jack G. Baldauf ${ }^{2}$ and John A. Barron ${ }^{3}$ \\ 'Department of Paleontology, University of California, Berkeley, California $94720^{*}$ \\ ${ }^{2}$ Ocean Drilling Program, Texas A\&M University, College Station, Texas 77843 \\ ${ }^{3}$ U.S. Geological Survey, 345 Middlefield Road, Menlo Park, California 94025
}

\begin{abstract}
A new diatom species, Thalassiosira praeoestrupii Dumont, Baldauf and Barron, is described. The first occurrence of $T$. praeoestrupii in coastal California diatom-bearing outcrops occurs between the last occurrence of Rouxia californica at 6.0 $\mathrm{Ma}$, and the first occurrence of Thalassiosira oestrupii at 5.1 Ma. The latter two species have customarily been used to identify the Miocene/Pliocene boundary. Paleomagnetic studies at Santa Cruz, California, demonstrate that the first occurrence of $T$. praeoestrupii coincides with the top of magnetic polarity Chron 5, which closely approximates the Miocene/Pliocene Epoch boundary.
\end{abstract}

\section{INTRODUCTION$$
\text { - }
$$

Diatoms are the predominant fossil group preserved in many of the sedimentary rock sequences of the late Miocene to earliest Pliocene in coastal California. Consequently, they are the main biostratigraphic tool for interpreting and differentiating the Miocene/Pliocene Epoch boundary (Hanna 1928; Wornardt 1967, 1983; Schrader 1973a; Barron 1975a, 1975b; Harper 1977; Rowell 1980; Dumont 1984). Recognition of the Miocene/Pliocene boundary in California has been a problem, as the sparseness of tropical microfossils makes correlation to the global time scale difficult (Burckle and Opdyke 1977). Thus, correlations to the tropics have been made through a series of stratigraphic sections containing mixtures of temperate and tropical diatoms (Barron 1981; Burckle and Opdyke 1985). In this way, the Miocene/Pliocene boundary has been placed between the last occurrence of Rouxia californica M. Peragallo in Tempere and Peragallo (1910) and the first occurrence of Thalassiosira oestrupii (Ostenfeld) Proschkina-Lavrenko (1956) in California (Barron and Keller 1983).

Recent time scales of Palmer (1983) and Berggren et al. (1985) place the Miocene/Pliocene boundary at, or slightly above the top of magnetic polarity Chron 5, with an estimated age of 5.3 Ma. Therefore, in California, the Miocene/Pliocene Epoch boundary falls within Barron's (1981) Subzone b of his Nitzschia reinholdii Zone. The last common occurrence of Rouxia californica lies in the upper part of magnetic polarity Chron 6 in California (Madrid 1982) and has an estimated age of about 6.0 Ma (Barron and Keller 1983). The first occurrence of Thalassiosira oestrupii is correlated to a level within the lower reversed event of the Gilbert polarity Chron in the equatorial Pacific by Burckle (1978) and has an estimated age of 5.1 Ma (Barron et al. 1985; Baldauf 1985).

Available correlations (Burckle 1978; Barron 1981) suggest that the $T$. oestrupii datum is isochronous between the tropics

*Present address: Chevron U.S.A. Inc., Exploration Department, P.O. Box 5024, San Ramon, California 94583-0942. and California. Consequently, the Miocene/Pliocene Epoch boundary in California is bracketed by diatom datums separated by 900,000 years. The $T$. oestrupii datum, used to approximate the boundary, is at least 200,000 years younger than the current estimated age of the boundary. Sediment accumulation rates in the nearshore basins commonly exceeded $200 \mathrm{~m} / \mathrm{m}$.y. during this time interval (Isaacs 1983; Barron and Keller 1983). Thus, approximating the epoch boundary through the use of the $T$. oestrupii datum could lead to errors on the order of $50 \mathrm{~m}$ in stratigraphic sections, making precise time correlations in the upper Neogene difficult.

Several outcrop sections in coastal California assignable to Subzone b of the Nitzschia reinholdii Zone have been examined in detail for diatom biostratigraphy. Schrader's (1973b) sample preparation technique was used. Four slides (cover glass size $22 \times 30 \mathrm{~mm}$ ) per sample were made from the processed residue; two of these were sieved through a less than 7- $\mu \mathrm{m}$ sieve. Hyrax, with a cured index of refraction of 1.71 was used as the mounting medium. All four slides were examined under a light microscope at $\times 500$ magnification, with species identifications confirmed at $\times 1250$. A diatom which closely resembles $T$. oestrupii, but ranges stratigraphically below the first appearance of $T$. oestrupii was discovered. Harper (1977, p. 93) noted the presence of a form resembling $T$. oestrupii in core material from Deep Sea Drilling Project Site 32. However, this form contained a wider separation between the pores than $T$. oestrupii sensu stricto. Harper (1977) chose to include this form with $T$. oestrupii, but noted that it ranged stratigraphically below the more typical $T$. oestrupii. The paleomagnetic stratigraphy completed for the Purisima Formation at Santa Cruz, California (Madrid 1982) indicated that the first appearance of this new diatom species, Thalassiosira praeoestrupii, occurs at the top of Chron 5. It thus coincides with the Miocene/Pliocene boundary at $5.3 \mathrm{Ma}$, as represented by Palmer (1983), and provides a more precise diatom datum for recognizing the Miocene/Pliocene Epoch boundary in California. Study of four additional sections in southern California support this new correlation. 
Genus THALASSIOSIRA Cleve 1873

Thalassiosira praeoestrupii Dumont, Baldauf and Barron, n. sp. Plate 1, figures $1-9,12$

Thalassiosira oestrupii (Ostenfeld, 1900).-PROSCHKINA-LAVRENKO, sensu Barron 1976a, p. 56, pl. 2, fig. 19; 1976b, p. 346, fig. $7 \mathrm{~b}$.

Holotype: Plate 1, figure 2.

Isotypes: Plate 1, figures 1, 3, 6, 7, 12.

\section{DESCRIPTION}

Valves circular, slightly convex, with diameters ranging between 16 and $33 \mu \mathrm{m}$ and averaging $25 \mu \mathrm{m}$ ( 8 valves measured). The polygonal areolae are arranged in sublinear to tangential rows, decreasing only slightly in size from the center of the valve (7-8 areolae in $10 \mu \mathrm{m})$ toward the margin (9-10 areolae in $10 \mu \mathrm{m})$. The decrease in size occurs about three-fourths of the distance from the valve's center to the margin. One small pore (or process) is centrally situated on the valve face between the areolae. One to three additional submarginal pores are situated at least four or five areolae distant from the central pore. Three rows of eccentrically arranged, diminutive polygonal areolae are present on the moderately introverted margin. Marginal spines are lacking.

\section{DISCUSSION}

Thalassiosira praeoestrupii is distinguished from $T$. oestrupii by the greater separation ( 4 to 5 areolae) between the central pore and the submarginal or secondary pore (or pores). Fryxell and Hasle (1980) reported that the two pores on the valve of $T$. oestrupii are separated by two or three areolae. The decrease in areolae size from the valve center to the margin is also less dramatic in $T$. praeoestrupii than in $T$. oestrupii. Fryxell and Hasle (1980) reported that $T$. oestrupii possesses six to nine areolae in $10 \mu \mathrm{m}$ near the center of the valve, and 9 to 12 areolae in $10 \mu \mathrm{m}$ near the valve's margin, implying a decrease in size of three to four areolae per $10 \mu \mathrm{m}$ over the valve's radius. The observed decrease in areolae size along the radius of $T$. praeoestrupii is only two areolae per $10 \mu \mathrm{m}$, as the central areolae range from seven to eight areolae in 10 $\mu \mathrm{m}$, and submarginal areolae range from 9 to 10 areolae in $10 \mu \mathrm{m}$.

\section{DISTRIBUTION}

Thalassiosira praeoestrupii occurs at eight widely spaced localities in coastal California (text-fig. 1), where it is typically rare, never more than $2 \%$ of the assemblage. Thalassiosira praeoestrupii was recorded from the lowermost Capistrano Formation at Upper Newport Bay as $T$. oestrupii by Barron (1976a). Subsequently, Barron in Barron and Keller (1983) revised the range for $T$. oestrupii sensu stricto, placing it stratigraphically higher in the Capistrano Formation. Thalassiosira praeoestrupii is also recorded from the upper Modelo Formation in the type area of the Bolivina obliqua Zone of Kleinpell (1938) in southern California; from the Purisima Formation in northern California; from the Sisquoc Formation in central California; and from the Pullen Formation at Centerville Beach in Humboldt County of northern California.

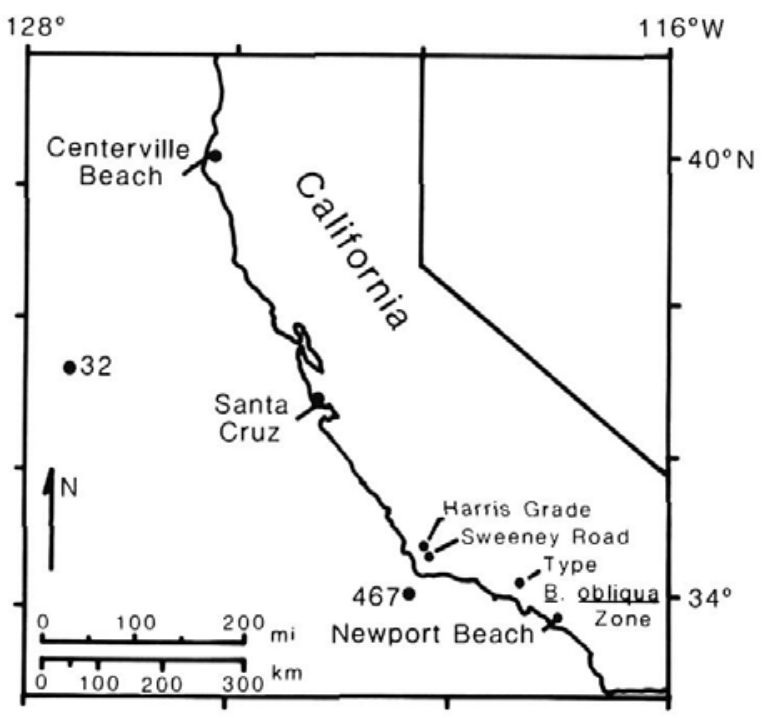

TEXT-FIGURE 1

Outline map of California showing the location of the onshore stratigraphic sections and offshore Deep Sea Drilling Project sites used for this study.

\section{STRATIGRAPHIC OCCURRENCE}

The first occurrence of Thalassiosira praeoestrupii marks the Miocene/Pliocene Epoch boundary in coastal California as indicated by the paleomagnetic stratigraphy of Madrid (1982) for the Purisima Formation, at Santa Cruz. It is also documented to occur between the last occurrence of Rouxia californica and the first occurrence of Thalassiosira oestrupii in the Newport Beach section near Newport, California, in the Sweeney Road and Harris Grade sections near Lompoc, and at Deep Sea Drilling Project Leg 63, Site 467 off southern California (table 1).

Madrid (1982) identified the uppermost part of magnetic polarity Chron 6 and all of Chron 5 in the lowermost 100 $\mathrm{m}$ of the Purisima Formation at Santa Cruz (text-fig. 2). At this locality the Purisima unconformably overlies the Santa Cruz Mudstone, which is massive to thick-bedded porcelaneous shale. Within the lowermost Purisima Formation, Madrid (1982) described a basal glauconitic sandstone, which is overlain by finely laminated to massive diatomite. A thin, white rhyolitic tuff overlies the diatomite, and a bioturbated and concreted diatomaceous sandstone overlies the tuff. This is followed by a thin, fine to medium sandstone and a thin shale unit. Stratigraphically above the shale is a thin, sandy unit which is a distinctive fossil bed containing numerous fossil crabs, and is referred to as the Crab Marker Horizon by Madrid (1982). The base of the Crab Marker Horizon coincides with the top of magnetic Chron 5 according to Madrid (1982) (text-fig. 2). A thick-bedded, pebbly quartzose sandstone overlies the Crab Marker Horizon.

Fifteen samples were collected for diatom study at roughly 10 -m intervals by Madrid, Dumont and Barron for Dumont's unpublished thesis research from the uppermost Santa Cruz Mudstone and lower Purisima Formation in 1984 (text-fig. 2). Diatoms were noted in all samples, but they are sparse and generally poorly preserved in the uppermost samples (numbers 14 and 15) above the Crab Marker Horizon. 


\section{PLATE 1}

All figures are of Thalassiosira praeoestrupii Dumont, Baldauf and Barron, n. sp., except 10 and 11, which are Thalassiosira oestrupii (Ostenfeld) Proschkina-Lovrenko (1956).

Note: All the illustrated specimens of Thalassiosira praeoestrupii on this plate are oriented so that the secondary pore is to the right, approximating the three o'clock position.

1 Isotype USNM 219029, USGS MR 358-MT 13. Diameter $20 \mu \mathrm{m}$. From the type Bolivina obliqua Zone, Modelo Formation from the exposure along Garrapata Canyon and Girard Highway north of Mohn Springs, Los Angeles County, California. This specimen was originally illustrated as $T$. oestrupii by Barron (1976b, fig. 7b). This form illustrates the nearly tangential areolation pattern, with the secondary pore situated five areolae away from the central pore toward the margin.

2 Holotype, USNM 403845; USGS MR 358-MT 13(17). Diameter $26.2 \mu \mathrm{m}$. From the type Bolivina obliqua Zone, in the lower part of Unit 18 of Hoots (1931) of the Modelo Formation, north of Mohn Springs between Garrapata Canyon and Girard Highway, Los Angeles County, California. This specimen shows the diagnostic character of four-areolae separation between the central and secondary pores, and the nearly tangential overall areolation pattern. Note also the moderately introverted margin with three rows of eccentrically arranged, diminutive polygonal areolae.

3 Isotype, USNM 403846; USGS MR 358-MT 13(7). Diameter $29.6 \mu \mathrm{m}$. From the Modelo Formation, type Bolivina obliqua Zone within the lower part of Unit 18 (Hoots 1931), north of Mohn Springs between Garrapata Canyon and Girard Highway, Los Angeles County, California. A variety of $T$. praeoestrupii with two centrally located pores separated by a single areola and the secondary pore located about four and a half areolae from the center toward the valve margin.

4 USGS MR 358-MT 13(5). Diameter $31.9 \mu \mathrm{m}$. From the Modelo Formation, Unit 18 of Hoots (1931), the type Bolivina obliqua Zone, north of Mohn Springs between Garrapata Canyon and Girard Highway, Los Angeles County, California. This specimen displays the sublinear areolation pattern suggestive of $T$. oestrupii. However, the decrease in areolae size from the center toward the margin is less dramatic than that of T. oestrupii.

5 USGS MR 358-MT 13(5). Diameter $33.0 \mu \mathrm{m}$. From the same horizon within the type Bolivina obliqua Zone, Modelo Formation, as the previous specimen. This specimen shows the variation of five areolae separating the central from the secondary pore.
6 Isotype, USNM 403848; USGS MR 358-MT 13(6). Diameter $22.8 \mu \mathrm{m}$. From the same locality as the previous specimen. This specimen illustrates the near tangential nature of the areolation pattern and five-areolae separation of the secondary pore from the central pore.

7 Isotype, USNM 403849; USGS MR 358-MT 13(6). From the same locality as the previously illustrated specimens. This specimen displays an areolation pattern that is similar to that of $T$. oestrupii. However, the secondary pore is approximately four and a half areolae distant from the central pore.

8-9 8, USGS MR 358-MT 13(7). Diameter $18.8 \mu \mathrm{m}$. 9, USGS MR 358-MT 13(5). Diameter $22.8 \mu \mathrm{m}$. These specimens are also from the type Bolivina obliqua Zone within the lower part of Unit 18 (Hoots 1931) of the Modelo Formation. Both specimens illustrate what appears to be a transitional stage with the $T$. oestrupiitype areolation pattern, but at least four areolae separate the central and secondary pores.

10 UCB-20. Diameter $26.2 \mu \mathrm{m}$. This specimen is from the massive diatomaceous shale, $485 \mathrm{~m}$ up from the base of the section at Sweeney Road, 2 mi east of Lompoc, California. This specimen resembles $T$. praeoestrupii with a nearly tangential areolae pattern, and a less dramatic decrease in the size of the areolae from the center to the margin of the valve. However, the secondary pore is approximately three areolae from the central pore as specified for $T$. oestrupii sensu stricto. This form appears to be a transitional form from $T$. praeoestrupii to $T$. oestrupii.

11 DSDP Leg 63, Site 467, sample 13-5. Diameter 19.4 $\mu \mathrm{m}$. This specimen displays the main diagnostic features for the species. Note the polygonal areolae arranged eccentrically, with a dramatic decrease in the size of the areolae from the valve center to the margin. There are also approximately three areolae separating the central and secondary pores.

12 Isotype, USNM 403847; H9A. Diameter $23.9 \mu \mathrm{m}$. From the Harris Grade section along Highway 1, about $6 \mathrm{mi}$ due north of Lompoc, California. This specimen has the nearly tangential areolation pattern accompanied by a less dramatic decrease in areolae size from the valve center to the margin than $T$. oestrupii. Secondary pore is separated from the central pore by approximately five areolae. 

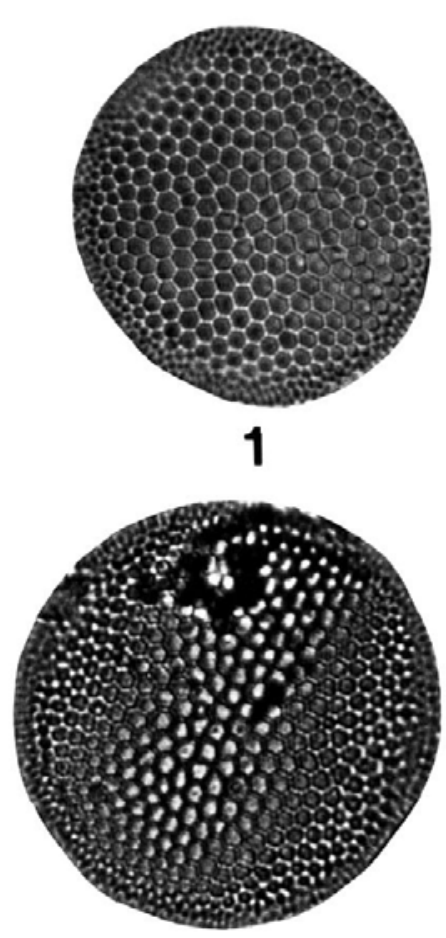

4
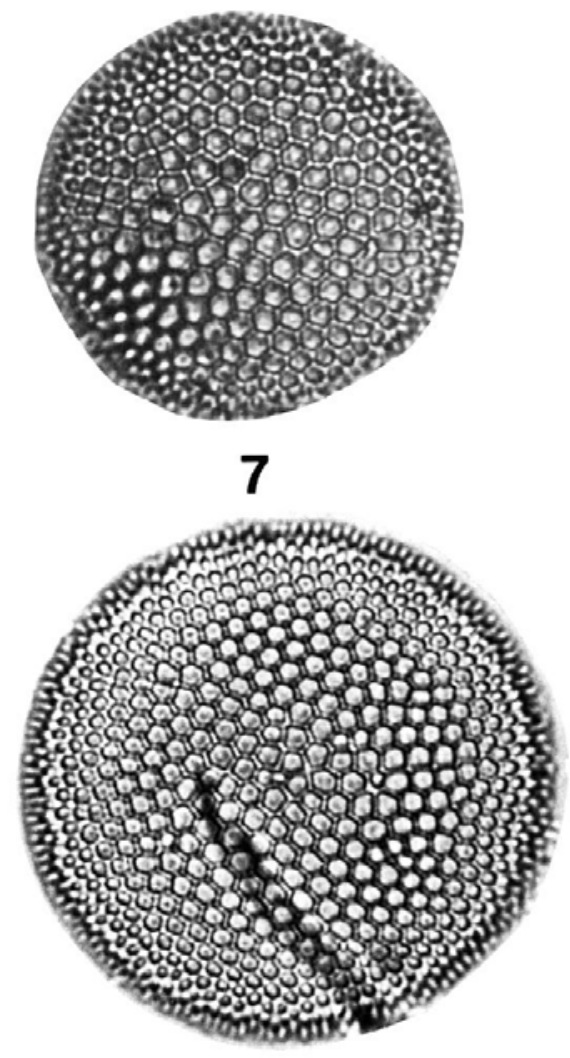

10

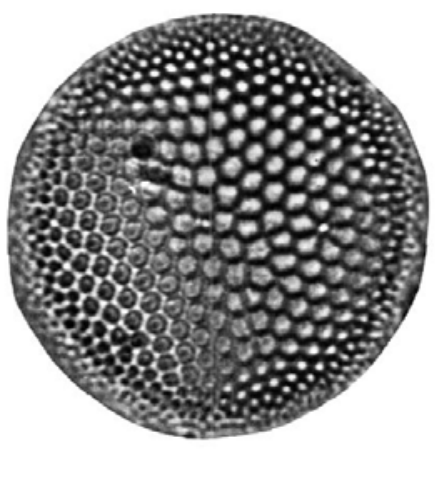

2

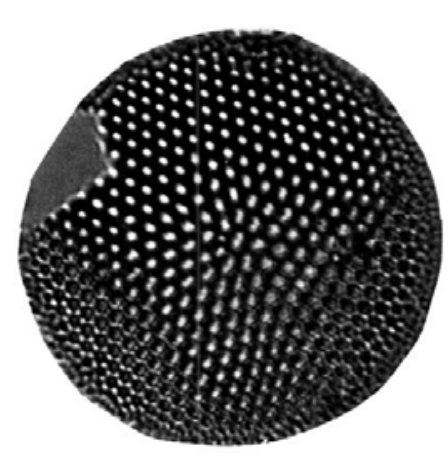

5
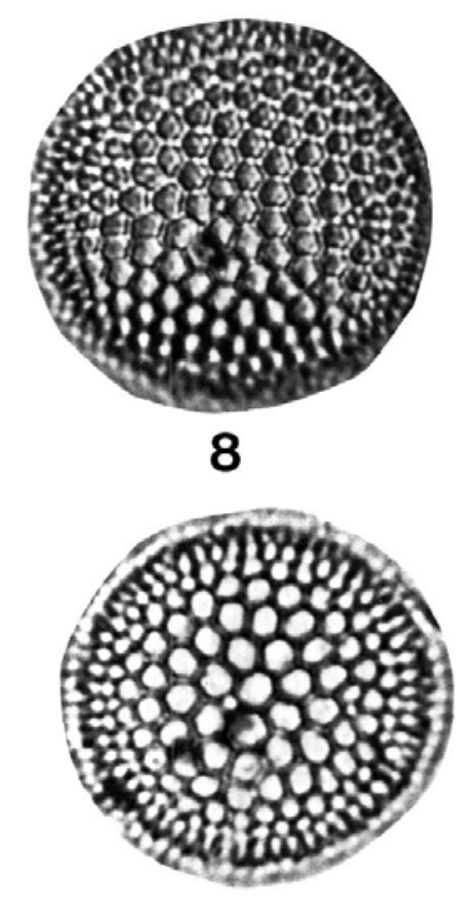

11

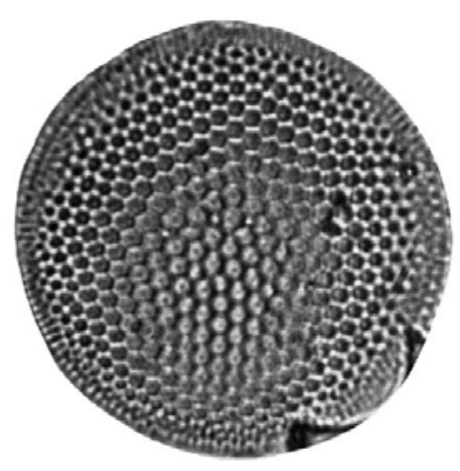

3

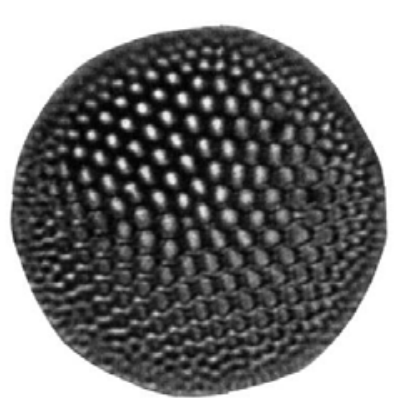

6
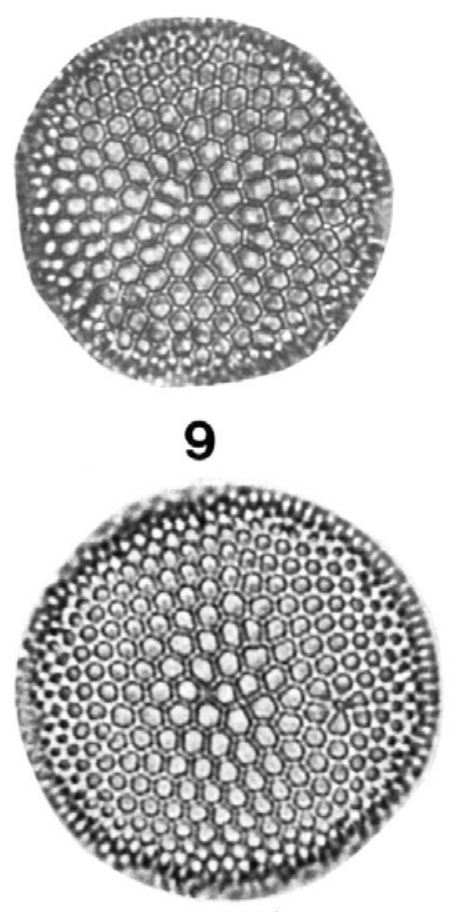

12 
TABLE 1

Stratigraphic succession of diatom datum levels across the Miocene/Pliocene Epoch boundary (5.3 Ma) in California sections. Sample number in section is given with stratigraphic interval of sample in brackets listed below. The diatom datums are designated as follows: $\mathrm{F}=$ first occurrence; $\mathrm{L}=$ last occurrence.

\begin{tabular}{|c|c|c|c|c|c|c|}
\hline Datum/Section & Age (Ma) & Purisima & Sweeney & Newport & 467 & Modelo \\
\hline F. $T$. oestrupii & 5.1 & - & $\begin{array}{c}19 / 20 \\
(475 \mathrm{~m})\end{array}$ & $\begin{array}{c}\mathrm{N} 19 \\
(420 \mathrm{~m})\end{array}$ & $\begin{array}{c}47-1(70-72 \mathrm{~cm}) \\
434.2 \mathrm{~m}\end{array}$ & - \\
\hline F. $T$. praeoestrupii & 5.3 & $\begin{array}{c}13 \\
(145 \mathrm{~m})\end{array}$ & $\begin{array}{c}18 / 19 \\
(452 \mathrm{~m})\end{array}$ & $\begin{array}{c}\mathrm{N} 14 \\
(371 \mathrm{~m})\end{array}$ & $\begin{array}{c}51-1(122-124 \mathrm{~cm}) \\
472.7\end{array}$ & $\begin{array}{c}\text { MT-13 } \\
(1015 \mathrm{~m})\end{array}$ \\
\hline L. R. californica & 6.0 & $\begin{array}{c}1 \\
(5 \mathrm{~m})\end{array}$ & $\begin{array}{c}3 \\
24 \mathrm{~m})\end{array}$ & $\begin{array}{c}\mathrm{N} 11 \\
(330 \mathrm{~m})\end{array}$ & - & $\begin{array}{c}\text { MT-5 } \\
(923.5 \mathrm{~m})\end{array}$ \\
\hline
\end{tabular}

Thalassiosira praeoestrupii first occurs in sample \#13 immediately below the Crab Marker Horizon and within the uppermost part of magnetic Epoch 5 (text-fig. 2). Consequently, the first occurrence of $T$. praeoestrupii closely approximates the Miocene/Pliocene boundary of Palmer (1983) and Berggren et al. (1985). Three additional significant diatom events were also identified in the Santa Cruz section (text-fig. 2). The first and last occurrences of Thalassiosira

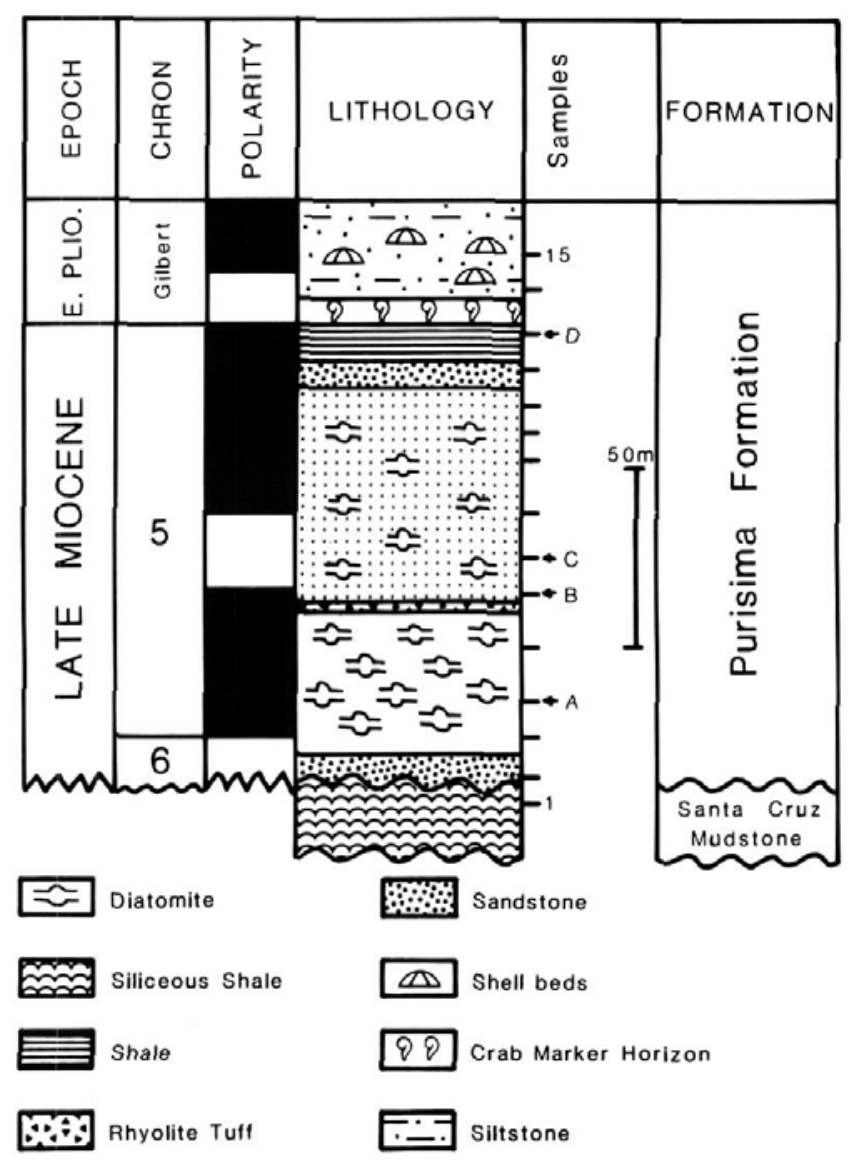

\section{TEXT-FIGURE 2}

A composite stratigraphic section of the uppermost Santa Cruz Mudstone and lower Purisima Formation with lithology and paleomagnetic stratigraphy after Madrid (1982). Four diatom events (A to D) are identified for the 15 samples collected in 1984: A = first occurrence of Thalassiosira miocenica; $\mathrm{B}=$ last occurrence of $T$. miocenica; $\mathrm{C}=$ first occurrence of $T$. hyalinopsis; and D = first occurrence of $T$. praeoestrupii. miocenica Schrader 1974 in the normal event of magnetic Epoch 5, appears to be environmentally controlled, because $T$. miocenica ranges entirely through magnetic Chron 5 in the equatorial Pacific (Burckle 1978). The first occurrence of Thalassiosira hyalinopsis Barron 1975 lies in the middle of the reversed magnetic event of Chron 5 (text-fig. 2). Barron (1975a) recognized $T$. hyalinopsis as a useful stratigraphic marker for the Sisquoc Formation near Lompoc, California.

This first occurrence event of $T$. praeoestrupii has been recorded $371 \mathrm{~m}$ above the base of the section in sample N-14 (Barron 1976a) of the lower Capistrano Formation from the western portion of Upper Newport Bay. It has also been found in the upper Modelo Formation in the lower part of Unit 18 of Hoots (1931), just below his sample 171, in sample USGS MR 358-MT 13 (Barron 1976b) (pl. 1, fig. 1), which is $1014.9 \mathrm{~m}$ above the base of the section at the type locality of the Bolivina obliqua Zone (Kleinpell 1938). In the central coastal region of California east of Lompoc, this diatom event was recorded in the massive diatomaceous shale of the lower Sisquoc Formation, approximately $452 \mathrm{~m}$ up-section from the small anticline found along Sweeney Road, which is about $2 \mathrm{mi}$ due east of Lompoc. In the massive siltstone of the Purisima Formation, the first occurrence of $T$. praeoestrupii is about $3 \mathrm{~m}$ below the distinct Crab Marker Horizon at Opal Cliffs along East Cliff Drive, about three and a half miles northeast of Soquel Point in Santa Cruz. To the north in Humboldt County, this diatom event is recorded within the massive, blue-gray siltstone of the Pullen Formation, which is about $110 \mathrm{~m}$ above the False Cape shear zone, at an exposed sea cliff section south of Centerville Beach. Paleomagnetic stratigraphy and the consistent diatom biostratigraphic occurrence strongly suggest that the first occurrence of $T$. praeoestrupii is coincident with the Miocene/Pliocene boundary at $5.3 \mathrm{Ma}$ in these coastal California sections (textfig. 1).

So far, the last occurrence of $T$. praeoestrupii has only been documented in one section, the Harris Grade section. Barron and Baldauf (1986) recorded the last occurrence of $T$. praeoestrupii in the Sisquoc Formation, $434 \mathrm{~m}$ above the base of the Harris Grade section.

\section{ACKNOWLEDGMENTS}

We express our thanks to Dr. Thomas Dignes and Peter Miller of Chevron U.S.A., and Dr. Charlotte A. Brunner of the University of California, Berkeley, for their advice, and 
initial readings of the manuscript. We are grateful to Dr. David Bukry of the U.S. Minerals Management Service and Dr. Howard E. Harper, Jr. of ARCO Exploration Company for their reviews and critical reading of the manuscript. We also thank Victor Madrid of Chevron U.S.A. for useful discussions about the Purisima Formation and for sharing his paleomagnetic data. Janice Salinas-Straw of Chevron U.S.A. and Michael Miller of the Staff Stratigraphic Laboratory of Chevron U.S.A. deserve thanks for technical support. M. P. Dumont also wishes to thank Beth A. Meinhard for her encouragement and support during this study.

\section{REFERENCES}

BALDAUF, J. G., 1985. A high resolution Late Miocene-Pliocene diatom biostratigraphy for the eastern equatorial Pacific. In: Mayer, L., Theyer, F., et al., Initial Reports of the Deep Sea Drilling Project, Volume 85:457-475. Washington, D.C.: U.S. Government Printing Office.

BARRON, J. A., 1975a. Marine diatom biostratigraphy of the Upper Miocene-Lower Pliocene strata of southern California. Journal of Paleontology, 49(4):619-632.

_ 1975 b. Late Miocene-Early Pliocene marine diatoms from southern California. Palaeontographica, 15(B):97-170.

- 1976a. Revised Miocene and Pliocene diatom biostratigraphy of Upper Newport Bay, Newport Beach, California. Marine Micropaleontology, 1:27-63.

,$- 1976 \mathrm{~b}$. Marine diatom and silicoflagellate biostratigraphy of the type Delmontian Stage and the type Bolivina obliqua Zone, California. Journal of Research U.S. Geological Survey, 4(3):339351.

, 1981. Late Cenozoic diatom biostratigraphy and paleoceanography of the middle-latitude eastern North Pacific, Deep Sea Drilling Project Leg 63. In: Yeats, R. S., Haq, B. U., et al., Initial Reports of the Deep Sea Drilling Project, Volume 63:507-538. Washington, D.C.: U.S. Government Printing Office.

BARRON, J. A., and BALDAUF, J. G., 1986. Diatom stratigraphy of the lower Pliocene Sisquoc Formation, Harris Grade section, California. Micropaleontology, 32(4):367-381 (present volume).

BARRON, J. A., and KELLER, G., 1983. Paleotemperature oscillations in the Middle and Late Miocene of the northeastern Pacific. Micropaleontology, 29(2):150-181.

BARRON, J. A., KELLER, G., and DUNN, D. A., 1985. A multiple microfossil biochronology for the Miocene. In: Kennett, J. P., Ed., The Miocene ocean: paleoceanography and biogeography. Geological Society of America Memoir, 163:21-36.

BERGGREN, W. A., KENT, D. V., FLYNN, J. J., and VAN COUVERING, J. A., 1985. Cenozoic geochronology. Geological Society of America Bulletin, 96(11):1407-1418.

BURCKLE, L. H., 1978. Early Miocene to Pliocene diatom datum levels for the equatorial Pacific. Second Working Group Meeting, Proceedings, Biostratigraphic Datum-Planes of the Pacific Neogene IGCP Project 114. Republic of Indonesia Ministry of Mines and Energy, Directorate General of Geological Research and Development Center, Special Publication, 1:25-44.

BURCKLE, L. H., and OPDYKE, N. D., 1977. Late Neogene diatom correlations in the circum-Pacific. Proceedings of the first International Congress on Pacific Neogene Stratigraphy, Tokyo, Kaiyo Shuppan, 1976:255-284.

_ 1985 . Latest Miocene-earliest Pliocene diatom correlations in the north Pacific. In: Kennett, J. P., Ed., Miocene ocean: pa- leoceanography and biogeography. Geological Society of America Memoir, 163:37-48.

CLEVE, P. T., 1873. On diatoms from the Arctic Sea. Bihang till Kongliga Svenska Vetenskaps-Akademiens Handlingar, 1(13):128.

DUMONT, M. P., 1984. Miocene/Pliocene Epoch boundary from diatom biostratigraphy in the Lompoc, California region. Abstracts with Programs 1984, 97th Annual Meeting, Geological Society of America, Reno, Nevada, 16(6):496.

FRYXELL, G. A., and HASLE, G. R., 1980. The marine diatom Thalassiosira oestrupii: structure, taxonomy and distribution. American Journal of Botany, 67(5):804-814.

GERSONDE, R., and SCHRADER, H., 1984. Marine planktic diatom correlation of the lower Messinian deposits in the western Mediterranean. Marine Micropaleontology, 9:93-110.

HANNA, G. D., 1928. The Monterey Shale of California at its type locality with a summary of its fauna and flora. American Association of Petroleum Geologists Bulletin, 12(10):969-983.

HARPER, H. E., JR., 1977. Diatom biostratigraphy of the MiocenePliocene boundary in marine strata of the circum-north Pacific. Ph.D. dissertation, Harvard University, $112 \mathrm{pp}$.

HOOTS, H. W., 1931. Geology of the eastern part of the Santa Monica Mountains, Los Angeles County, California. U.S. Geological Survey Professional Paper, 165-C:83-134.

ISAACS, C. M., 1983. Compositional variation and sequence in Miocene Monterey Formation, Santa Barbara coastal area, California. In: Larue, D. K., and Steel, R. J., Eds., Cenzoic marine sedimentation, Pacific margin, U.S.A. Pacific Section, Society of Economic Paleontologists and Mineralogists, Special Publication, 117-132.

KLEINPELL, R. M., 1938. Miocene stratigraphy of California. American Association of Petroleum Geologists, Tulsa, Oklahoma, $450 \mathrm{pp}$.

MADRID, V. M., 1982. Magnetostratigraphy of the late Neogene Purisima Formation, Santa Cruz County, California. Master's thesis, University of California, Davis, $103 \mathrm{pp}$.

PALMER, A. R., 1983. The decade of North American geology 1983 geologic time scale. Geology, 11(9):503-504.

ROWELL, H. C., 1980. Diatom biostratigraphy of the Monterey Formation, Palos Verdes Hills, California. Master's thesis, University of Southern California, $123 \mathrm{pp}$.

SCHRADER, H. J., 1973a. Cenozoic diatoms from the Northeast Pacific, Leg 18. In: Kulm, L. D., von Huene, R., et al., Initial Reports of the Deep Sea Drilling Project, Volume 18:673-797. Washington, D.C.: U.S. Government Printing Office.

, 1973b. Proposal for a standardized method of cleaning diatom-bearing deep-sea and land-exposed marine sediments. In: Simonsen, R., Ed., Second symposium on Recent and fossil marine diatoms, London, September 4-9, 1972, Proceedings, 403-409.

WORNARDT, W. W., JR., 1967. Miocene and Pliocene marine diatoms from California. California Academy of Science Occasional Papers, 63:65 pp.

- 1983. The Sisquoc Formation is Pliocene in age and the Monterey Formation is Miocene in age in the Santa Maria area, Santa Barbara County, California. Programs and Abstracts, 58th Annual Meeting, Pacific Sections AAPG, SEG, SEPM, Sacramento, California, May 18-21, 1983:58.

Manuscript received February 13, 1986.

Manuscript accepted April 16, 1986. 